their instinctive desire to make use of this knowledge to carry out an ambitious and brutal war program, have built a Frankenstein monster which bids fair to destroy them.

\section{WAR DISTURBANCES AND PEACE READJUSTMENTS IN THE CHEMICAL INDUSTRIES}

By Grinnili Jones

Chemist on the staff of United States Tariff Commission

When peace is restored the competitive strength of the nations in all industries will have been profoundly altered. Chemistry and machinery have played a larger part in this war than in any previous war, and therefore the greatest changes may be expected in the metal working and in the chemical industries. Moreover, our new American cargo ships will make is more than ever interested in foreign trade. The Tariff Commission is actively studying these war disturbances in order to assist in the readjustment and reconstruction that must follow when peace comes.

Among the chemical industries, the first to feel the stimulus of war was the explosives industry. The expansion of American smokeless powder plants was sufficient to prevent a German victory in France and Russia in 1915. It is not revealing military secrets to say that there has been some growth since I915. We all hope that the peace terms will be so satisfactory that the military explosives plants themselves will no longer be needed. Nevertheless, there will be a permanent increase in the competitive strength of the American chemical industries through the growth of the subsidiary industries which now supply the raw materials to the explosives industry.

Our production of sulfuric acid is at least twice what it was before the war. The growth has been largely in contact acid, and therefore when the demand for explosives disappears, the American chemical industries will have available large supplies of pure and concentrated sulfuric acid. Moreover, the growth of the acid industry has been made possible by a great increase in the production of American sulfur and by a smaller, although significant, increase in the mining of pyrites.

The nitric acid industry has grown relatively more than the sulfuric acid industry. The output of nitric acid from Chilean niter is now more than ten times as great as it was before the war.

The significance of this growth of the sulfuric and the nitric acid industries to our dynamite, dyestuffs, and pyroxylin plastic industries need not be emphasized here.

Of greater significance than this stimulus to industries already well established has been the birth of new industries. We have a new synthetic ammonia and nitric acid industry. Plants have been built and, during the war at least, will be operated by the Government. When the full story of these plants can be told, it will reveal that American chemists have, under the pressure of war needs, been able to devise substantial itmprovements upon the Haber and Ostwald processes developed by the Germans before the war. These processes were the result of nearly two decades of work on these problems as a part of their military preparedness. It is not improbable that after the war nitric acid made from synthetic ammonia may prove to be cheaper than nitric acid made from Chilean niter. In any case, American agriculture will assuredly have a new large source of nitrogenous fertilizer materials.

In I9I4 our production of crude light oil would have been sufficient for the production of only about $4,500,000$ gallons of benzol and of about $x, 500,000$ gallons of toluol, and only a part of this was distilled. As is shown in our forthcoming report on the production of American dyes and coal-tar chemicals, in I9I7 our output of benzol was 40,200,000 gallons, of toluol, I0,200,000 gallons. In 1918 further substantial growth is to be expected through the installation of stripping plants at city gas works. The toluol is now going almost entirely into explosives as is also a considerable fraction of the benzol. When the demand for explosives disappears, it is to be expected that the prices of benzol and toluol will drop to the point where it will be profitable to add them to gasoline for motor fuel. A similar condition will probably exist abroad and, since America has the greatest known natural resources for the production of gasoline, benzol and toluol should be as cheap or cheaper here than abroad. Therefore the industries consuming benzol and toluol may be assured of ample supplies of these materials at favorable prices.

Before the war we had no synthetic phenol industry, whereas in 1917 , as is shown in our forthcoming report, $I_{5}$ plants produced $64,146,499 \mathrm{lbs}$. of phenol valued at $\$ 23,715,805$, most of which was used in making picric acid. If this new industry is to survive, there must be a greater consumption of phenol in the industries for peaceful purposes. Fortunately, phenol is used as an intermediate in the manufacture of some representatives of every class of finished coal-tar chemical products, including dyes and lakes, photographic developers, medicinals, flavors, perfume materials, synthetic resins, synthetic tanning materials, and explosives. Leaders in the chemical industries are already making plans for the industrial development of the uses of phenol when the phenol is no longer needed for explosives.

Another war-baby is monochlorbenzol, which was made during 1917 by eight American firms, with an output of $24,624,099$ lbs., valued at a little less than $\$ 5,000,000$. The dye industry will use a part of this productive capacity permanently, but new discoveries by American chemists will probably be needed to utilize the total productive capacity. Incidentally, this product furnishes a new outlet for chlorine, a new by-product source of muriatic acid, and raises a new problem in the utilization of dichlorbenzol, an unavoidable by-product.

Before the war there was but one producer of aniline oil in the United States. In 1917 there were twenty-three producers with an output of $28,806,524 \mathrm{lbs}$., valued at $\$ 6,758,535$. As only a relatively small proportion of this substance goes into explosives, the peace readjustments will not be complicated by a collapse of a military demand, but will depend primarily on the competitive strength of the American industry.

The war has also stimulated the production of mercury for the manufacture of fulminates. The American production has been about doubled since the beginning of the war. Formerly we had a balance of imports-now we have a larger balance of exports.

Poison gas warfare is also destined to have a permanent influence on the chemical industries. Although there is no reason to expect that uses will be found for phosgene and mustard gas on a scale approaching the present and prospective military use, the plants erected for their manufacture need not prove a total loss when the military demand ceases. Nearly all of the noxious substances used in poison gas warfare require chlorine for their manufacture, and an increase in the production of chlorine in the United States is therefore certain. There is much hope that some of the substances produced as intermediate steps in the manufacture of the poison gases may be utilized for purposes other than warfare, but these are matters not yet to be discussed. Phosgene, except for the dangers attending its use, is an excellent reagent for many processes involving chlorination or dehydration and for making Michler's ketone. Fortunately, the risk in using phosgene is greatly minimized by the development of the new gas mask. The intensive work which hundreds of American chemists have been and are doing to improve the design of the gas mask will undoubtedly prove a blessing to workmen exposed to noxious fumes in chemical factories throughout the world when peace is restored.

Still another industry which has been stimulated by a direct war demand is the manufacture of acetone, which is used as a 
gelatinizing agent in the manufacture of the explosive, cordite; as a solvent for airplane dopes; and in the manufacture of poison gases. Before the war, acetone was obtained entirely as one of the products of the wood distillation industry, but there are now at least four new processes in commercial operation in the United States or Canada for the manufacture of acetone.

It has been found that glicose can be fermented by a suitable organism to give acetone directly. Butyl alcohol is a by-product of this fermentation and becomes commercially available in appreciable amounts. The development of uses for butyl alcohol is an attractive problem.

The other processes for making acetone produce acetic acid or an acetate as an intermediate step, and may therefore permanently affect the acetic acid industry. The most obvious and perhaps the simplest of these processes depends on fermenting molasses to alcohol, which is then converted into acetic acid by the rapid vinegat process. The conversion of acetic acid into acetone is an old and well-known process but the details have been improved.

Another process depends on making acetylene from calcium carbide. By the aid of a suitable catalyst, the acetylene is made to combine with water yielding acetaldehyde which may be readily oxidized to acetic acid. Still another process depends on fermenting kelp under such conditions that sodium acetate and potassium salts are secured.

The war has stimulated the production of many other products, a few of which may be briefly mentioned: castor oil for lubricating airplane motors; phosphorlus for incendiary bombs and smoke screens; barium and strontium nitrates for signal rockets. The output of soda ash has increased by 68 per cent since 1914, and the output of caustic soda has more than doubled.

New conditions in the chemical industries have also been created by the curtailment of imports. As a direct consequence of this stoppage of imports from Germany, a new American dye industry has been established. It is true that some dyes were being made in the United States before the war, but the makers relied on Germany for the necessary intermediates, with the exception of a small amount of aniline made here by a single producer. During 1917,134 different intermediates were made by 118 firms. One firm made 53 different intermediates. Dyes were made by $8 \mathrm{I}$ firms. The total production of dyes in the United States during 1917 was approximately equal in gross weight to the annual importations before the war. The exports of American dyes exceeded in value, although not in quantity or variety, our imports before the war. The dye industry is not dependent on any imported raw material except sodium nitrate from Chile. Many important dyes are still lacking, but indigo and alizarin are now on the market in significant amounts, and the vat dyes for cotton derived from anthracene are coming.

A new potash industry has also arisen, but its future does not seem so promising as the future of the new dye industry. Here Germany has an inherent geological and geographical advantage. Although shipments from Germany ceased early in IgI5 and although prices have advanced to about ten times the pre-war prices, the American production during $I_{9} I_{7}$ was only about $I_{3}$ per cent of our pre-war consumption. This relatively small production was obtained from many sources and by many processes. There is an excellent prospect that the recovery of potash as a by-product of cement will survive German competition and ultimately supply about one-third of our needs. In addition, significant amounts will probably be secured as a by-product of the pig iron blast furnace. That the other branches of the potash industry can survive German competition is open to serious question.

Within a few months after, the outbreak of the war, imports to the United States from Germany and her Allies came to an end. As the months went by, it became increasingly difficult to obtain cargo space for imports from any part of the world. Now the limiting factor in the American participation in the war is shipping for our troops and their supplies, and therefore ships are no longer free to seek the most profitable cargo and route, but are being assigned to routes and cargoes by the Shipping Board on the basis of military needs rather than profits. The Shipping Board has organized a Division of Planning and Statistics, which is making a study of world commerce and the military and civil requirements, for the purpose of utilizing available shipping in a way that will contribute most to the winning of the war. Military requirements make it essential that an abnormally large proportion of the world's shipping shall be used in the North Atlantic. This has made it necessary to curtail imports from other parts of the world to essential requirements.

The chemist on the staff of the Shipping Board is W. B. D. Penniman, of Baltimore. He must decide what chemicals need not be imported at all, and the amounts of others which must be imported to supply essential needs. The importance of this work can perhaps best be made clear by an example. The Shipping Board, after consultation with the Food Administration, decided that ships could not be spared for the importation of tapioca from Java and the Straits Settlements. The War Trade Board accordingly announced that licenses for the importation of tapioca would not be granted. Efforts were immediately made to secure a modification of this order on behalf of one of the manufacturers of nitro-starch for the Army and on behalf of manufacturers of mucilage for the Post-Office Department. Nitro-starch has been improved until it is now one of the safest of all explosives to handle and finds important military uses. Until a few months ago it was being made from tapioca. Penniman, however, succeeded in convincing the officers of the War Department and the manufacturers that a satisfactory product could be made from cornstarch. The details of the manufacture have been worked out coöperatively by the starch producers, the manufacturers of nitro-starch, and the experts of the War Department with such success that nitro-starch from corn is not only better but more economically produced than nitro-starch from tapioca. The Post-Office Department also readily agreed to use some locally available material instead of tapioca for mucilage on stamps. The shipping saved on this one item of tapioca for nitro-starch is sufficient to transport and sustain in France more than twenty-five thousand fighting men. Mr. Penniman's services to the nation on questions of this character deserve to be better known and appreciated. Imported materials for the time being should be used with the utmost economy and only for essential needs. American chemists can render valuable public service by finding substitutes for materials which must be imported from overseas.

It seems probable that many of the discoveries in regard to the use of substitutes for imported materials made under this pressure of war needs will prove of permanent value and have a permanent influence on international trade.

A third source of war disturbances in the chemical industry has been due to the diversion of materials from their customary use to war uses. The fertilizer industry has probably made the greatest sacrifices of this sort. Sodium nitrate and ammonia are required for the manufacture of explosives in such large quantities that the amounts left for use in fertilizers has been and will be much reduced. Raw phosphate rock has of course been plentiful but the acid used in the manufacture of acid phosphate has been largely diverted to making explosives. The relatively small supplies of potash have been very high in price and normal amounts have not been available at any price. The peace readjustments may, however, be expected to bring compensation to the fertilizer industry. Large new supplies of nitrogenous fertilizer materials will be available from the new nitrogen fixation plants. The new and enlarged sulfuric acid 
plants must again find the chief outlet for their product in the making of fertilizers. Finally, the German monopoly of the potash market is likely to be broken through the French control of Alsace and the new developments in America and Spain. It is therefore reasonable to expect a large increase in the manufacture and use of fertilizers with a resulting benefit to all producers and consumers of food.

Chlorine also is likely to be diverted from its normal uses to the manufacture of poisonous gases to a considerable extent. In spite of the erection of new plants we may all be asked to use paper lacking in the whiteness to which we have been accustomed. Chemists in industries using chlorine should prepare to facilitate this diversion now, and plan to use more chlorine later when the military demand ceases.

It is evident that the status quo ante cannot be reëstablished in the chemical industries any more than it can be rëstablished in international relations. Peace will bring new conditions of international competition and radical readjustments in industry from a war basis to a peace basis.

The Tariff Commission is endeavoring to secure and have ready for immediate use all information likely to be helpful to Congress in determining the part which the tariff is to play in these readjustments. We desire information in regard to the industrial development and technical progress of industries throughout the world; in regard to the sources of their raw materials and the uses of their products; and in regard to any changes in conditions likely to have a permanent influence on costs of production or the competitive strength of industries here and abroad. The assistance and coöperation of manufacturers, importers, and consumers in the collection and interpretation of this information is desired.

\section{CHEMICAL WARFARE RESEARCH}

By WILDER D. BANCROF'T

Lieutenant Colonel, Chemical Warfare Service, U. S, A.

As Dr. Parsons has told you, the Bureau of Mines started a research laboratory in gas warfare about a year and a half ago. On July first that was taken over by the War Department, but the organization as it stands at present is practically the same as that developed by the Bureau of Mines. The outward signs of the change are that Major General Sibert is the official head instead of Mr. Manning, and that Mr. G. A. Burrell is now Colonel Burrell. On the other hand, Dr. E. P. Kohler, who had charge of all the offense problems, holds the same position in the new organization without having put on a uniform.

Instead of running over the various sections and outlining their duties, it seems to me that it would be a good deal more interesting, though perhaps less thorough, if I described the procedure in regard to any given war gas.

The term "war gas" is a flexible one. The substance may be a liquid, a solid, a vapor, or a true gas. However, it must have some pretty striking characteristics: it must be poisonous; or produce tears (lachrymatory); or must give rise to nausea, sneezing, or blisters; have a foul smell, though otherwise harmless; or be a smoke with obscuring powers. Of course it may have any or all of these properties combined. Under any of these circumstances we call it a war gas. It must also have certain other characteristics. It must be pretty good in its class. Nowadays no one would consider as a toxic substance anything which did not kill dogs in $30 \mathrm{~min}$. at a concentration of I $\mathrm{mg}$. per liter. It is that effective concentration which is overlooked by people who suggest new gases or methods of using old ones. In the case of lachrymatory substances they should be effective at concentrations as low as $O$. OI $\mathrm{mg}$. per liter. The best are much better than that.
Another determining factor in the use of any gas is the availability of raw materials. Where thousands of tons may be needed, there is no use in considering a substance of which the available output per year is a gram, a ton, or a hundred tons.

A good method of manufacture should be at hand. If the substance is good enough, it will be made by any method, however wasteful; but this is not true in most cases. I could cite an instance where a substance would be used if a good method of manufacture were available. The present method of making this substance is so wasteful that its good qualifications do not counterbalance the disadvantages, and it is not used either by our Allies or by ourselves.

A substance must be stable, or fairly stable. It must not polymerize rapidly, hydrolyze too rapidly, be too inflammable, or go to pieces on detonation. Our problem is different from that of the Allies because the Allies can use their material within 2 or 3 months after loading the shells, whereas in our case shell loading here must take place from 3 to 6 months before firing, and consequently our limits as to stability against polymerization must be more rigid than those of the British and French; and as a matter of fact the French are using certain substances which we shall not use, just because of those conditions.

How do we start with any given substance? We may take a substance already used by the Germans or the Allies, or we may get a suggestion from outside, or the staff may think up something from a search of the literature, from analogy, or from pure inspiration. Then steps are taken to see whether it can be considered as a toxic substance. First, the Offense Research Section, under Dr. Lauder Jones, makes the substance. If it is a solid, it is sent to the Dispersoid Division, Dr. R. C. Tolman in charge, and they work out methods of disintegrating it.

When this is done, or if it is a liquid or vapor, it is sent to the Toxicological Section, Dr. A. S. Loevenhart, and tested to determine degree of toxicity, concentration producing lachrymation, or any other of the delightful characteristics. If their report is favorable, the substance is turned over to a number of different sections.

The Offense Research Laboratory works to improve the laboratory method of making. After they have worked this out on a laboratory scale, the substance is turned over to the Chemical Production Section, Mr. W. S. Rowland, and they work it out on a larger scale, from 50 lbs. to a ton, depending entirely on the nature of the substance. It then goes outside of the Research Division, either to Large Scale Production (Colonel Dorsey) for further development, or direct to Colonel Walker, at Edgewood, for commercial production either there or to be assigned to some manufacturer somewhere in the country. While the Offense Research Section is working out an improved laboratory method, the substance is sent to the Analytical Section, under the charge of Mr. A. C. Fieldner. They develop methods for determining its purity. They also analyze mixtures in air. It is sometimes difficult to determine substances at the dilution in use. They also make tests to find out whether the canisters will stop the substance.

It is also sent to the Pyrotechnic Section under Mr. G. A. Richter to determine stability when fired in shells, that is, whether it goes to pieces under the detonating charge.

At the same time the Defense Research Section, under Dr. A. B. Lamb, is working to determine whether any change in the ingredients put in the canister is necessary. If the substance is not absorbed, some new mixture or compound must be developed which will stop it. This Section also takes up the question of methods of detecting toxic substances in the field. That might be considered to be a problem for the Analytical Section, but our whole system is pretty flexible, and as a matter of fact that work has been done by the Defense Research Section, of course working in coöperation with the Analytical Section. 